УДК 347.44

DOI https://doi.org/10.32849/2663-5313/2021.3.10

\title{
Альона Силкіна,
}

аспірантка кафедри иивільного права № 1

Національного юридичного університету імені Ярослава Мудрого

\section{СПОСОБИ ЗАХИСТУ ТЕЛЕФОРМАТУ У ПРАВІ ІНТЕЛЕКТУАЛЬНОЇ ВЛАСНОСТІ}

Для кожного твория, правовласника телевізійного формату важливо забезпечити належний захист телевізійного формату. Без належного захисту прав інтелектуальної власності буде неможливим міжнародне співробітничтво й укладення договорів з контрагентами з різних країн. У статті аналізуються дві основні форми захисту прав інтелектуальної власності - юрисдикиійна та неюрисдикиійна. Застосування різних способів захисту є важливим у відносинах, що виникають у спорах, щодо телевізійних форматів.

На міжнародному рівні формат є новим об’єктом дослідження в праві інтелектуальної власності, тому законодавство щодо формату лише на стадії формування. Проте неурядові й урядові організаиї, такі як FRAPA та WIPO, розробляють нові способи захисту для чутливого об'єкта права IB-формату. Захищаючи формат як об'єкт права інтелектуальної власності, необхідно класифікувати елементи, з яких він складається, на групи відповідно до порушеного права. Так як формат складається з елементів, що охороняються авторським правом, та елементів, котріє утилітарними й охороні не підлягають, суб'єктам, права яких порушено, необхідно обрати належний спосіб захисту порушеного права.

Задля недопущення порушення прав на формат суб'єкти мають здійснити превентивні заходи захисту. У статті наводиться комплекс необхідних превентивних заходів: реєстрація авторського права, реєстрачія ТМ, підписання договорів про передачу прав на використання творів, розмішення комериійної інформаиї в иифрові сейфи WIPO Proof, I-Depot тощо. Цифрові сейфи WIPO Proof та i-Depot є додатковим способом захисту иінних цифрових активів, творів, дизайну продуктів, винаходів, комериійної таємниці, ідеї, навіть висновків продюсерів, отриманих у процесі розробок формату.

Правові системи охороняють об'єкти IB, наприклад, за допомогою патентного права, авторського права й реєстрачією товарних знаків, завдяки чому твориі отримують визнання або фінансову винагороду за свої винаходи, твори. Забезпечуючи баланс інтересів винахідників $і$ сочіуму, система права інтелектуальної власності сприяє створенню умов для розвитку творчості й інноваиій.

Ключові слова: авторське право, аудіовізуальний твір, класифікація форматів, складний комплексний об’єкт права інтелектуальної власності, телевізійний формат.

Постановка проблеми. Створення об'єктів права інтелектуальної власності потребує значних затрат часу, фінансів і творчої праці. Недобросовісні конкуренти, бажаючи отримати легкі гроші нелегальним шляхом, крадуть чужі ідеї та видають їх за власні. Незахищеність формату на певній території робить непривабливою таку систему законодавства для продавців форматів. Україна намагається гармонізувати законодавство відповідно до Європейських і міжнародних стандартів захисту права інтелектуальної власності. Форми захисту права інтелектуальної власності різняться залежно від країн.

Варто зазначити, що формат як об'єкт права інтелектуальної власності переважно досліджувався в працях зарубіжних учених, серед яких - В. Горчаков, В. Дозорцев, Г. Карнел, О. Кулініч, Р. Мідоу, А. Моран, Т. Орен, Б. Сойка, Д. Чалабі та ін. Проте на національному рівні не аналізувалися мож- ливі способи захисту формату, а також превентивні заходи, такі як використання цифрових сейфів від ВОІС, Бенілюксу тощо.

Мета статті - розглянути особливості юрисдикційних і неюрисдикційних способів захисту форматів; класифікувати національні способи захисту та міжнародні, які використовуються суб'єктами телевізійної сфери; проаналізувати наявні класифікації різних науковців, сформулювати підхід щодо захисту прав на формат, а також визначити превентивні заходи забезпечення прав володіння форматом.

Виклад основного матеріалу. У національному законодавстві розрізняють дві основні форми захисту прав інтелектуальної власності - юрисдикційну й неюрисдикційну. Юрисдикційна форма захисту прав інтелектуальної власності полягає в тому, що особа, права якої порушено, звертається 
за захистом порушених прав до суду, інших компетентних державних органів, уповноважених ужити необхідні заходи для відновлення порушених прав і припинення правопорушення. У рамках юрисдикційної форми захисту прав, у свою чергу, виокремлюють загальний (судовий) і спеціальний (адміністративний) порядки захисту порушених прав інтелектуальної власності [4, с. 55].

Кожна особа має право звернутися до суду за захистом свого особистого немайнового або майнового права та інтересу відповідно до статті 16 Цивільного кодексу України (далі - ЦКУ). Неюрисдикційна форма захисту прав інтелектуальної власності передбачає дії юридичних і фізичних осіб щодо захисту прав інтелектуальної власності, які здійснюються ними самостійно (самозахист), без звернення за допомогою до державних або інших компетентних органів. Також способи захисту в праві інтелектуальної власності можна класифікувати на дві групи: загальні (котрі передбачені в статті 16 ЦКУ) та спеціальні (статті 276, 278, 279, 280 ЦКУ та статті Закону України (далі - ЗУ) «Про авторське право і суміжні права»). Наприклад, якщо порушуються права на елементи телевізійного формату, котрі підлягають захисту відповідно до ЗУ «Про авторське право та суміжні права», доцільно використовувати способи захисту, передбачені статтями 50 і 50-2 цього Закону За захистом свого авторського права й (або) суміжних прав суб'єкти авторського права та суміжних прав мають право звертатися в установленому порядку до суду й інших органів відповідно до їхньої компетенції.

Спосіб захисту залежить від того елементу, який привалює у форматі або який порушено. Інколи правопорушник копіюе одразу декілька елементів, звичайно, захищатися буде кожен елемент і фізична особа має обрати належний спосіб захисту. При захисті прав на формат суд може постановити рішення про застосування негайних заходів щодо запобігання порушенню прав інтелектуальної власності й збереження відповідних доказів; зупинення пропуску через митний кордон України об'єктів, імпорт чи експорт яких здійснюється з порушенням прав інтелектуальної власності; застосування разового грошового стягнення замість відшкодування збитків за неправомірне використання об'єкта права інтелектуальної власності тощо. Власнику прав інтелектуальної власності дається можливість вибору способу захисту порушених прав. Суб'єкт має право на власний розсуд вимагати або відшкодування заподіяних збитків, або стягнення на свою користь доходу, одержаного правопорушником унаслідок пра- вопорушення, або виплати компенсації. Якщо порушено немайнові права інтелектуальної власності, зокрема принижено честь, гідність автора, творця або завдано шкоди діловій репутації власника прав, то така моральна шкода відшкодовується грішми, іншим майном або в інший спосіб.

Науковець А. Горчаков до поширених випадків порушення прав на телевізійний формат зараховує такі: виробництво телевізійного продукту, схожого до ступеня змішування з іншим, уже наявним; неправомірне отримання доступу до ноу-хау правовласника формату; використання ідентичних і (або) подібних слоганів; копіювання творчого складника; незаконне отримання конкурентних переваг (недобросовісна конкуренція). Варто враховувати, що національні законодавства по-різному трактують на перший погляд подібні поняття. Недобросовісна конкуренція може бути у формі введення в оману клієнта (покупця, глядача) або незаконного отримання конкурентних переваг або ж полягати в паразитичній діяльності особи, що порушує права й інтереси правовласника формату. Наявні відмінності в національних законодавствах іноді призводять до того, що формат, успішно захищений на одній території, виявляється таким, що не підлягає охороні на іншій [3, с. 99].

На нашу думку, при захисті формату як об’єкта права інтелектуальної власності необхідно розділити об'єкти на групи відповідно до порушеного права. Так, усі елементи телевізійного формату поділяються на охоронювані об'єкти (сценарій, музика, зображення, комерційне найменування, образ ведучих, персонажі тощо) і ті, які не підлягають охороні авторським правом (ідея, бізнес-інформація). О. Кулініч виділяє у творі «юридично байдужі» та «юридично значущі» елементи. До юридично байдужих, тобто неохоронюваних елементів твору художньої літератури, зараховані тема, матеріал твору, сюжетне ядро, ідейний зміст. Їх запозичення не накладає на користувачів ніяких обов'язків, тобто не є порушенням авторського права. До юридично значимих (охоронюваних) елементів твору належать образи й мова твору. До об'єктів, що не охороняються авторським правом, належать передусім ті з них, які не володіють хоча б однією 3 ознак твору науки, літератури й мистецтва. Якщо особою в результаті зробленого досягнутий не творчий, а суто технічний результат, він нормами авторського права не охороняється. До такого роду результатів належать, зокрема, телефонні довідники, розклади руху, адресні книги тощо за умови, що упорядником не застосована оригінальна 
система викладу довідкових даних [5, с. 120]. Групування елементів формату дає змогу побудувати правильну стратегію їх захисту й застосувати належним чином способи захисту, котрі передбачені цивільним законодавством. Наприклад, «юридично байдужі» елементи або утилітарні необхідно захищати в порядку договірного права, а «юридично значущі» - через реєстрацію авторських прав як превентивний спосіб, через судовий позов - як реальний захід.

Зазвичай в Україні телевізійний формат захищається шляхом реєстрації авторського права на літературний твір - сценарій. Першою спробою захисту прав на телевізійний формат була справа «Караоке на майдані» проти «Караоке біля фонтану» [8]. Проте автори відстоювали своє право лише на один елемент формату - сценарій, котрий включений у Державний реєстр свідоцтв про реєстрацію авторського права. На жаль, у 2001-2005 роки українська телевізійна спільнота не оперувала категорією «формат», а тому захищалися певні елементи, які підпадали під захист авторського права. Важливо поєднувати способи захисту й захищати одразу декілька елементів телевізійного формату, такі дії підвищують охороноспроможність формату загалом.

Необхідно здійснити комплекс дій: реєстрацію авторського права на сценарій, реєстрацію ТМ (наприклад, назва телепередачі), підписання договорів про передачу прав на використання творів (музики, сценарію, текстів), максимальну фіксацію будь-якого етапу розробки формату, створення біблії формату (докладний опис реалізації формату, реєстрація доменних імен, укладання договорів про конфіденційність 3 потенційними покупцями, яким ви пітчите формати, реєстрація опису формату як літературного твору (отримання свідоцтва про авторське право)), помістити комерційну інформацію в цифрові сейфи WIPO Proof, I-Depot тощо.

3 одного боку, деякі елементи не підпадають під захист авторського права, проте не варто відхиляти інші механізми захисту об'єктів, які передбачені цивільним законодавством. Чинне законодавство передбачає широкий перелік способів захисту, які можуть використовуватися при невизнанні, оспорюванні авторського права й суміжних прав [5, с. 93]. Загалом продюсери використовують при захисті форматів нетипові реєстраційні системи. Однією з ефективних і популярних систем є база телевізійних форматів FRAPA [1]. Використовуючи систему реєстрації формату FRAPA (FRS), фізична або юридична особа реєструє власні творчі напрацювання, завантажуючи до системи
ФРАПА: сценарій, опис ідеї, сюжетні лінії та різну документацію, яка стосується телевізійного формату. Після рішення Верховного суду Великобританії у 2016 році біблії використовувалися для визначення форматів як «драматичних творів» та, отже, придатних для захисту авторських прав.

Ще одним альтернативним вирішенням суперечок щодо формату є ВОIВ. У квітні 2010 року FRAPA об'єднала зусилля з ВОIB у рамках співпраці ВОIВ призначає експерта зі своєї групи медіаторів та арбітрів з питань кіно та ЗМІ для нагляду за переговорами, спрямованими на досягнення практичних рішень. Можливі способи вирішення спорів варіюються від домовленостей про сплату ліцензійного збору до навмисного розмежування спірного формату.

В Україні медіа групи також є членами організації ФРАПА та вдаються до захисту телевізійних форматів через механізми передбачені організацією. Наприклад, найбільша українська медіа група StarLightMedia приєдналася до FRAPA, провідної міжнародної асоціації визнання та захисту форматів з 2016 року. Також до спору, котрий розглядався у 2019 році Верховним Судом України, між Новим каналом «Ревізор» проти каналу 1+1 «Інспектор Фреймут» залучався аналіз ФРАПА як доказу. Експерти з FRAPA оцінили, чи «Інспектор Фреймут» $є$ копією формату «Ревізор», використовуючи інформацію (включаючи посилання на відео), надану Новим каналом. Верховний Суд підтвердив порушення прав Нового Каналу й фактично захистив права на телевізійний формат «Ревізор».

Станом на 2020 рік в Україні з'явився ще один конфлікт з приводу прав на формат. У недобросовісній конкуренції знову звинувачується телевізійний канал «1+1», а саме підробці формату «The Masked Singer» у програмі «Маскарад». Телевізійний канал «Україна» збирається подавати позов до суду й звернутися щодо захисту своїх прав до Міжнародної організації з визнання та захисту форматів FRAPA (Format Recognition and Protection Association). До розгляду підключили FRAPA, і їі експерти погодилися: проекти «Маскарад» на каналі 1+1 i «Маска» на каналі «ТРК Україна» схожі на 73\%.

На нашу думку, формат необхідно захищати комплексно: юрисдикційними та неюрисдикційними способами захисту. Твердження, що формат не можна захистити авторським правом, а тому він не підлягає захисту, загалом є помилковим. Бюро інтелектуальної власності Бенілюксу (BОIP) надає послугу будь-яким фізичним і юридичним особам в охороні їхньої конфіденційної 
інформації й навіть ідей у спеціальних цифрових сейфах. Тобто так можна захистити будь-які елементи телевізійних форматів Телевізійні компанії в діяльності можуть використовувати цифрові сейфи i-DEPOT для зберігання інформації в конфіденційності. Наприклад, телевізійна компанія має ідею нового телевізійного формату й не бажає, щоб за межами компанії хтось дізнався, як працює продукт або відбувається процес зйомок. Або є інформація, і компанія приховує її від конкурента: бухгалтерські записи, бази даних клієнтів, напрацювання продюсерів, пілотні випуски програм тощо. Компанія може визначити перелік цінної інформації й захистити її як комерційну таємницю. Щоб мати змогу вжити законних заходів у разі крадіжки, важливо зберігати свою комерційну таємницю в таємниці та активно захищати. Це можна зробити за допомогою угод про нерозголошення й зберігаючи їх у цифровому сейфі, такому як i-DEPOT. Суд відповідної країни вирішить, чи допускати його до провадження. Європейські суди завжди приймають i-DEPOT як доказ.

27 травня 2020 року ВОІВ запровадила нову нотаріальну бізнес-послугу для новаторів у будь-якій галузі - «WIPO PROOF». «WIPO PROOF» - це цифрова нотаріальна послуга, що створює відбиток дати й часу на цифровому файлі - токен. Для створення токену використовується найвищий стандарт технології інфраструктури відкритих ключів, що відповідає стандарту RFC 3161. «WIPO PROOF» дає змогу створити захищені від несанкціонованого втручання докази того, що цифровий файл із вашими інтелектуальними активами існував у певний момент часу та що в нього не вносилися зміни.

Телевізійний формат не є об'єктом авторського права, а тому його складно захистити звичними реєстраційними системами права інтелектуальної власності. WIPO Proof дає суб’єктам цивільного права можливість підтвердити існування ідеї та творчих напрацювань у момент створення оригінального формату, що має принципове значення для його захисту від потенційного незаконного привласнення або посягань. Автори можуть використовувати маркери WIPO PROOF для підтвердження того, що вони створили оригінальний об'єкт раніше, ніж інші. Телевізійні програми є результатом праці кількох авторів. Доцільно враховувати існування кожного окремого елементу при захисті формату. WIPO PROOF дає змогу вести окремий облік віршів, сценарію, музичних творів і готових продуктів, що $є$ цінним для вирішення в майбутньому потенційних суперечок щодо авторства [2]

\section{Висновки}

Формат - це комплексний об'єкт, захист кожного елементу не може обмежуватися виключно авторським правом. Навіть унікальна комбінація так званих «утилітарних» або «байдужих елементів» може підтверджувати факт подібності двох телевізійних форматів, що, безперечно, свідчить про порушення прав власника формату. Головною рекомендацією для організацій мовлення є превентивні заходи захисту: реєстрація прав на кожен елемент телевізійного формату (використання нових цифрових нотаріальних послуг від BOIB, Бенілюксу). Поєднання альтернативних способів захисту з тими, що передбачені законодавцем, надаватиме значні переваги при відстоюванні прав на формат у судовому чи арбітражному розгляді. Законодавець має враховувати нові тенденції, звернення суб'єктів телевізійного мовлення до неурядових організацій свідчить про неналежний рівень захисту форматів національною системою права.

\section{Список використаних джерел:}

1. FRAPA. Офіційний сайт неурядової організації захисту форматів. URL: https://frapa.org/ format-registration/ (дата звернення: 15.02.2021).

2. BOIC. Офіційний сайт. URL: https://www. wipo.int/wipoproof/ru/ (дата звернення: 15.02.2021).

3. Горчаков А.В. Правова природа формату аудіовізуального твору : монографія. Москва, 2013. C. 142.

4. Захист прав інтелектуальної власності: норми міжнародного і національного законодавства та їх правозастосування : практичний посібник / Л. Доріс та ін. Київ, 2007. 448 с.

5. Кулініч О.О. Правова охорона персонажу літературного твору як «юридично значимого» елемента твору. Актуальні проблеми держави $i$ права. 2010. Вип. 53. С. 126-131. URL: http:// nbuv.gov.ua/UJRN/apdp_2010_53_19. ВOIP (дата звернення: 15.02.2021) ; Оффіиійиий сайт організаиії з прав IC країн Бенілюксу. URL: https://www. boip.int/en/entrepreneurs/ideas/your-idea-in-ani-depot\#i-depot-trade-secret-and-know-how (дата звернення: 15.02.2021).

6. Посібник для суддів з інтелектуальної власності / І.М. Бенедисюк та ін. Київ, 2018. 424 с. URL: http://www.nsj.gov.ua/files/1541665727 IntellProperty_Handbook_.pdf (дата звернення: 15.02.2021)

7. Про авторське право і суміжні права : Закон України від 14.10.2020 № 3792-XII. URL: https:// zakon.rada.gov.ua/laws/show/3792-12 (дата звернення: 15.02.2021).

8. Судове рішення № 22-ц-7206/2010. URL: https://reyestr.court.gov.ua/Review/11862909\# (дата звернення: 15.02.2021).

9. Цивільний кодекс України : Закон України від 16 березня 2003 р. № 435-IV. URL: https:// zakon.rada.gov.ua/laws/show/435-15 (дата звернення: 15.02.2021). 
Alena Sylkina. Ways of the protection of a TV format in intellectual property law

It is important for every creator and owner of a television format to ensure properprotection of the television format. Without appropriate protection of intellectual property, rights international cooperation and signing contracts with counterparties from different countries will not be possible. This article analyzes two main forms of protection of intellectual property rights - jurisdictional and non-jurisdictional. The use of different methods of protection is important in the relations that arise in disputes over television formats.

At the international level, the format is a new subject of research in the law of intellectual property, so the legislation on the format is only at the stage of formation. However, non-regulatory organizations such as FRAPA and WIPO are developing new ways of protection for such a sensitive subject as the format. When capturing format as an object of intellectual property rights it is necessary to classify the elements of which it is composed into groups according to the violated right. So, as the format is composed of elements protected by copyright and elements that are utilitarian and not protected. Subjects, whose rights are violated, it is necessary to address the appropriate way to protect the violated right.

In order to prevent the violation of the rights to the format, the subjects have to take preventive measures of protection. This article provides a set of necessary preventive measures: copyright registration, trademark registration, signing agreements on the transfer of rights for the use of works, placement of commercial information in digital safes WIPO Proof, I-Depot, etc. WIPO Proof and i-Depot digital safes are an additional means of preserving valuable digital assets, creations, product designs, intellectual property, commercial secrets, ideas, and even opinions of producers obtained in the course of format development.

Legal systems protect IP objects, for example, through patent law, copyright and trademark registration, by which the creators receive recognition or financial reward for their works and creations. Ensuring the balance of interests of owners and society, the system of intellectual property rights creates conditions for the development of creativity and innovation.

Key words: copyright, audiovisual work, television format, complex object of intellectual property rights. 